\title{
PERBANDINGAN MODEL PEMBELAJARAN DISCOVERY LEARNING DAN NUMBERED HEADS TOGETHER MELALUI MEDIA WORD SQUARE TERHADAP HASIL BELAJAR KOGNITIF PESERTA DIDIK PADA SUB MATERI STOIKIOMETRI
}

\author{
Sheila Amalia ${ }^{1}$, Riska Imanda ${ }^{2 *}$, Fakhrah $^{3}$ \\ ${ }^{123}$ Program Studi Pendidikan Kimia, Universitas Malikussaleh \\ Email: riska.imanda07@ unimal.ac.id \\ *corresponding autor
}

\begin{abstract}
Abstrak
Penelitian ini bertujuan untuk mengetahui bagaimana perbandingan model pembelajaran Discovery Learning dan Numbered Heads Together melalui media Word Square terhadap hasil belajar kognitif peserta didik pada sub materi stoikiometri di SMA Negeri 1 Dewantara. Jenis penelitian yang digunakan adalah quasi experimental design berbentuk nonequivalent control group design. Teknik pengambilan sampel yang digunakan adalah purposive sampling, sampel pada penelitian ini adalah kelas X IPA 2 sebagai kelas eksperimen yang diajarkan menggunakan model pembelajaran Discovery Learning dan kelas X IPA 1 sebagai kelas kontrol yang diajarkan menggunakan model pembelajaran Numbered Heads Together. Data bersumber dari hasil observasi, wawancara, dan soal tes berbentuk pilihan berganda. Hasil penelitian menunjukkan bahwa terdapat peningkatan hasil belajar yang signifikan pada kelas eksperimen dan kelas kontrol. Rata-rata pretes kelas eksperimen $=4,56$ dan kelas kontrol $=4,41$ sedangkan pada postes kelas eksperimen $=16,29$ dan kelas kontrol $=14,88$. Uji hipotesis melalui Independent sample $t$-test pada SPSS versi PASW 18 menunjukkan sig. (2-tailed) 0,22. Sesuai dengan kaidah keputusan menggunakan uji Levene sig. < 0,05 maka $\mathrm{H}_{0}$ ditolak $\mathrm{H}_{\mathrm{a}}$ diterima.
\end{abstract}

Kata Kunci: Discovery Learning, Hasil Belajar, Numbered Head Together, Model Pembelajaran, Stoikiometri

\begin{abstract}
This study aims to determine how the comparison of Discovery Learning models and Numbered Heads Together through the Word Square media to the cognitive learning outcomes of students in the stoichiometry sub material at SMA Negeri 1 Dewantara. The type of research used is quasi experimental design shaped nonequivalent control group design. The sampling technique used was purposive sampling, the sample in this study is class X Science 2 as an experimental class using Discovery Learning model and class X Science 1 as a control class using the Numbered Heads Together model. Data sourced from observations, interviews, and multiple choiche test questions. The results showed that there was a significant increase in learning outcomes in the experimental class and the control class. The average pretest of the experimental class $=4,56$ and control $=4,41$ while the posttest of the experimental class $=16,29$ and the control class $=14,88$. Hypothesis testing through Independent sample t-test on SPSS version PASW 18 shows sig. (2-tailed) 0,22. According to the rules of the decision using the test levene sig. $<0,05$ the $\mathrm{H}_{0}$ is rejected $\mathrm{H}_{\mathrm{a}}$ is accepted.
\end{abstract}

Keywords: Discovery Learning, Learning Outcomes, Numbered Heads Together 


\section{PENDAHULUAN}

Pendidikan yang bermutu dapat diwujudkan melalui sumber daya yang bermutu. Pendidikan yang bermutu adalah pendidikan yang mampu mengembangkan potensi-potensi positif yang terpendam dalam diri peserta didik sehingga menghasilkan tenaga-tenaga muda berpotensi yang tangguh dan siap bersaing dalam masyarakat luas (Widodo, 2015: 294). Pendidikan yang sesuai dan berkualitas adalah suatu kegiatan belajar mengajar yang didukung oleh proses pembelajaran yang efektif, peserta didik cepat memahami apa yang diajarkan, pembaharuan kurikulum, peningkatan kualitas guru, pengadaan sarana dan prasarana yang lengkap pada masingmasing sekolah. Perkembangan yang terjadi sampai saat ini, menunjukkan bahwa masalah yang serius dalam peningkatan kualitas pendidikan di Indonesia adalah rendahnya kualitas pendidikan di berbagai jenjang pendidikan, baik pendidikan formal maupun informal (Putrayasa, dkk., 2014: $1)$.

Hasil observasi dan wawancara dengan guru bidang studi kimia yang telah dilakukan di SMA Negeri 1 Dewantara bahwa masalah utama yang banyak ditemui dalam kegiatan pembelajaran adalah rendahnya hasil belajar kognitif peserta didik yang disebabkan oleh lemahnya proses pembelajaran yang berlangsung. Faktor penyebab lemahnya proses pembelajaran yaitu: pembelajaran yang selama ini dilakukan cenderung berpusat pada guru, peserta didik kurang bersemangat dalam belajar disebabkan oleh penggunaan model pembelajaran yang tidak bervariasi dan cenderung monoton, peserta didik kurang mengerti istilah-istilah yang muncul dalam pelajaran kimia, peserta didik tidak mampu memahami dan menggunakan rumus dalam perhitungan kimia karena peserta didik tidak mengingat dasar-dasar kimia dengan baik dan peserta didik kesulitan memahami konsep-konsep kimia baik secara abstrak maupun kompleks. Hal ini sesuai dengan pernyataan Kurniawati, dkk (2017) yang menyatakan bahwa, pentingnya pembelajaran kimia ini mengakibatkan peserta didik dituntut untuk menguasai materi-materi pada pembelajaran kimia mencakup konsep dan perhitungan, yang menjadi prasyarat untuk memahami materi-materi pada pembelajaran kimia.

Berdasarkan uraian permasalahan di atas, berakibat fatal pada Kriteria Ketuntasan Minimal (KKM) untuk mata pelajaran kimia bab stoikiometri yang telah ditetapkan yaitu 65. Materi stoikiometri yang dipandang sulit adalah sub materi hukum-hukum tentang gas dan interkonversi mol-gram-volume sehingga bagian ini besar pengaruhnya terhadap KKM stoikiometri. Menurut salah satu guru bidang studi kimia di sekolah tersebut, hasil belajar kognitif peserta didik jika dinyatakan berdasarkan fakta hampir tidak memenuhi KKM dilihat dari hasil rata-rata ulangan harian bab stoikiometri yang diperoleh selama 2 tahun terakhir berturut-turut yaitu 60 dan 63, jika dirata-ratakan maka masingmasing kelas dari 7 kelas X IPA hanya 5 sampai 15 dari 30 peserta didik yang berhasil mencapai KKM.

Solusi untuk mengatasi permasalahan ini yaitu dengan menerapkan model pembelajaran Discovery Learning dan Numbered Heads Together dengan menggunakan media Word Square. Menurut Hosnan (dalam Monasari dan Pintor, 2018: 30) menyatakan bahwa, discovery learning adalah suatu model untuk mengembangkan cara belajar peserta didik aktif menemukan sendiri, menyelidiki sendiri, maka hasil yang diperoleh akan setia dan tahan lama 
dalam ingatan, tidak akan mudah dilupakan oleh peserta didik. Peserta didik juga bisa belajar berpikir analisis dan mencoba memecahkan sendiri masalah yang dihadapi dengan belajar penemuan. Melalui model pembelajaran ini, peserta didik diharapkan menemukan sendiri dan mentransformasikan informasi kompleks, mengecek informasi baru dengan yang sudah ada dalam ingatannya, dan melakukan pengembangan menjadi informasi atau kemampuan yang sesuai dengan lingkungan dan zaman, tempat dan waktu ia hidup.

Model pembelajaran Numbered Heads Together adalah teknik belajar mengajar yang memberikan kesempatan kepada semua peserta didik untuk saling membagikan de-ide dan mempertimbangkan jawaban yang paling tepat. Selain itu juga mendorong peserta didik untuk meningkatkan semangat kerja sama mereka. Word Square merupakan media yang digunakan melalui Lembar Kerja Peserta Didik (LKPD), Word Square berupa huruf yang disusun secara acak dan merupakan jawaban dari pertanyaan-pertanyaan yang tersedia dalam LKPD. Tujuan penelitian ini adalah untuk mengetahui bagaimana perbandingan model pembelajaran Discovery Learning dan Numbered Heads Together melalui media Word Square terhadap hasil belajar kognitif peserta didik pada materi stoikiometri di SMA Negeri 1 Dewantara.

\section{METODOLOGI PENELITIAN}

Pendekatan yang digunakan dalam penelitian ini adalah pendekatan kuantitatif, jenis penelitiannya adalah Quasi Experimental Design (desain eksperimen semu). Desain ini mempunyai kelompok kontrol, tetapi tidak dapat berfungsi sepenuhnya untuk mengontrol variabel-variabel luar yang mempengaruhi pelaksanaan eksperimen
(Sugiyono, 2016: 114). Desain eksperimen semu memiliki dua bentuk desain, namun dalam hal ini peneliti memilih bentuk desain Nonequivalent control group design. Desain ini hampir sama dengan Pretest-postest control group (Sugiyono, 2016: 116).

Tabel 1. Desain Penelitian

\begin{tabular}{|c|c|c|c|}
\hline $\begin{array}{c}\text { Kelompok } \\
\text { Perlakuan }\end{array}$ & Pretes & Perlakuan & Postes \\
\hline Eksperimen & $\mathrm{O}_{1}$ & $\mathrm{X}_{1}$ & $\mathrm{O}_{2}$ \\
\hline Kontrol & $\mathrm{O}_{3}$ & $\mathrm{X}_{2}$ & $\mathrm{O}_{4}$ \\
\hline
\end{tabular}

(Sumber: Sugiyono, 2016: 116)

Keterangan :

$\mathrm{O}_{1}=$ Pretes kelas Discovery Learning

$\mathrm{O}_{3}=$ Pretes kelas NHT

$\mathrm{X}_{1}=$ Pembelajaran Discovery Learning

$\mathrm{X}_{2}=$ Pembelajaran NHT

$\mathrm{O}_{2}=$ Postest kelas Discovery Learning

$\mathrm{O}_{4}=$ Postes kelas NHT

Penelitian ini dilakukan di SMA Negeri 1 Dewantara yang beralamat di jalan BTN Arun Paloh Lada, Krueng Geukueh, kecamatan Dewantara, Kabupaten Aceh Utara, Provinsi Aceh. Penelitian ini dilaksanakan pada semester genap Tahun Ajaran 2018/2019. Populasi dalam penelitian ini adalah seluruh peserta didik kelas X IPA SMA Negeri 1 Dewantara tahun ajaran 2018/2019 yang terdiri dari 7 kelas dengan jumlah total peserta didik 210 orang.

Penentuan sampel dalam penelitian ini menggunakan teknik purposive sampling, yaitu berdasarkan hasil uji homogenitas dan normalitas yang telah dilakukan oleh guru di sekolah tersebut. Adapun yang menjadi sampel dalam penelitian ini adalah kelas $X$ IPA 2 sebagai kelas eksperimen yang diajarkan menggunakan model pembelajaran Discovery Learning dan Kelas X IPA 1 sebagai kelas kontrol yang diajarkan menggunakan model pembelajaran Numbered Heads Together.

Data yang dikumpulkan dalam penelitian ini bersumber dari hasil

KATALIS Jurnal Penelitian Kimia dan Pendidikan Kimia

Page 3 
observasi, wawancara tidak terstruktur, serta hasil pretes dan postes. Instrumen yang digunakan dalam penelitian ini adalah Lembar Kerja Peserta Didik (LKPD) kimia pada materi pokok hukum-hukum tentang gas dan interkonversi mol-gram-volume sejumlah 2 LKPD dan soal pretes serta soal postes yang berbentuk pilihan berganda (multiple choice).

Uji N-gain digunakan untuk mengetahui peningkatan hasil belajar peserta didik baik dari kelas eksperimen maupun kelas kontrol. Uji normalitas digunakan untuk mengetahui apakah sampel yang diperoleh berdistribusi normal atau tidak. Uji ini dilakukan untuk mengetahui apakah kedua sampel penelitian yang dibandingkan memiliki varians homogen. Uji homogenitas juga perlu dilakukan agar diketahui bahwa data yang diperoleh akan diolah menggunakan statistik parametris atau nonparametris (Sugiyono, 2016: 210211). Uji hipotesis dalam penelitian diolah dengan menggunakan SPSS PASW 18 menggunakan uji Levene dengan menguji selisih nilai pretes dan postes dari hasil belajar peserta didik. Uji pihak yang digunakan adalah uji $\mathrm{t}$ dua pihak dengan taraf signifikasi $\alpha=0,05$.

\section{HASIL DAN PEMBAHASAN}

Berdasarkan hasil penelitian yang telah dilakukan di SMA Negeri 1 Dewantara maka dilakukan uji prasyarat analisis terhadap data yang diperoleh. Adapun data yang dianalisis dari hasil pretes dan postes adalah uji N-gain, Normalitas dan Homogenitas. SPSS PASW Statistic 18 digunakan untuk mempermudah pengolahan data.

\section{1) N-Gain}

Skor hasil pretes dan postes yang diperoleh, digunakan untuk menghitung $\mathrm{N}$-Gain sesuai tabel dan gambar berikut ini:
Tabel 2. Uji N-Gain Berdasarkan Hasil

Skor Pretest dan Postest

\begin{tabular}{|c|c|c|c|c|c|c|c|}
\hline \multicolumn{7}{|c|}{ Descriptive Statistics } \\
\hline & $\mathrm{N}$ & Min & Max & Sum & Mean & $\begin{array}{c}\text { Std. } \\
\text { Deviation }\end{array}$ & Variance \\
\hline $\begin{array}{c}\text { Pretes_eks } \\
\text { perimen }\end{array}$ & 34 & 2 & 8 & 155 & 4,56 & 1,501 & 2,254 \\
\hline $\begin{array}{c}\text { Postest_ek } \\
\text { sperimen }\end{array}$ & 34 & 10 & 20 & 554 & 16,29 & 2,329 & 5,426 \\
\hline $\begin{array}{c}\text { Pretes_kon } \\
\text { trol }\end{array}$ & 32 & 0 & 6 & 141 & 4,41 & 1,500 & 2,249 \\
\hline $\begin{array}{c}\text { Postest_ko } \\
\text { ntrol }\end{array}$ & 32 & 10 & 19 & 476 & 14,88 & 2,685 & 7,210 \\
\hline N_gain & 66 &, 04 &, 16 & 7,67 &, 1163 &, 02906 &, 001 \\
\hline $\begin{array}{c}\text { Valid N } \\
\text { (listwise) }\end{array}$ & 32 & & & & & & \\
\hline Summber: SPSS PASW & & & & \\
\hline
\end{tabular}

(Sumber: SPSS PASW 18)

Berdasarkan Tabel 2, diperoleh rata-rata hasil pretes kelas eksperimen yang menggunakan model pembelajaran Discovery Learning dan kelas kontrol yang menggunakan model pembelajaran Numbered Heads Together yaitu 4,56 dan 4,41 dengan skor total 100, sedangkan rata-rata hasil postesnya yaitu 16,29 dan 14,88 . Hasil analisis menunjukkan nilai rata-rata $\mathrm{N}$-Gain antara kelas eksperimen lebih tinggi dibandingkan dengan kelas kontrol, sehingga terdapat perbedaan hasil belajar peserta didik pada kedua kelas tersebut.

Selisih skor N-Gain antara kelas eksperimen dan kelas kontrol ditunjukkan pada Gambar 4.1 dan lampiran 7 skripsi ini. Rata-rata skor N-Gain kelas eksperimen adalah 11,50 dengan kriteria tinggi sedangkan kelas kontrol adalah 10,24 dengan kriteria tinggi. Berdasarkan data tersebut dapat dilihat bahwa dari kedua kelas yang diuji terdapat peningkatan rata-rata hasil belajar kognitif peserta didik.

\section{2) Uji Normalitas}

Uji normalitas bertujuan untuk mengetahui secara pasti bahwa data yang diperoleh berdistribusi normal atau tidak. Data dikatakan berdistribusi normal apabila nilai signifikan $>0,05$. Hasil uji normalitas terhadap data tersebut disajikan dalam tabel dan grafik pada gambar berikut: 
Berdasarkan hasil uji normalitas, diperoleh data hasil uji normalitas pada Shapiro-Wilk dengan nilai signifikan 0,064 untuk kelas eksperimen dan 0,380 untuk kelas kontrol yang berarti $>0,05$. Hal ini menunjukkan bahwa data berdistribusi normal baik kelas eksperimen maupun kelas kontrol.

\section{3) Uji Homogenitas}

Uji homogenitas bertujuan untuk mengetahui perbandingan antara kelas eksperimen dan kelas kontrol. Varians data dapat dikatakan homogen jika sig. > 0,05 . Berikut ini adalah tabel hasil uji homogenitas:

Tabel 3. Uji Homogenitas

\begin{tabular}{|c|c|c|c|}
\hline \multicolumn{4}{|c|}{ Test of Homogenity of } \\
Variances \\
\hline \multicolumn{4}{|c|}{ N_gain } \\
\hline $\begin{array}{c}\text { Levene } \\
\text { Statistic }\end{array}$ & df1 & df2 & Sig. \\
\hline 2,297 & 1 & 64 &, 135 \\
\hline
\end{tabular}

(Sumber: SPSS PASW 18)

Berdasarkan Tabel 3, diperoleh hasil uji statistik homogenitas dengan nilai signifikan sebesar 0,135 yang berarti $>0,05$. Maka data yang diperoleh miliki varians yang homogen.

\section{4) Uji Hipotesis}

Uji hipotesis dilakukan setelah diketahui data berdistribusi normal dan homogen. Uji hipotesis bertujuan untuk mengambil keputusan hipotesis manakah yang akan diterima dari $\mathrm{H}_{0}$ dan $\mathrm{H}_{1}$. Untuk mengetahui hal tersebut maka dilakukan pengolahan data melalui Independent Sample T-test pada PASW Statistic 18 sebagai berikut:

Berdasarkan hasil analisis uji hipotesis dengan menggunakan PASW Statistic 18 diperoleh sig (2-tailed) yaitu 0,022 . Sesuai dengan kaidah keputusan menggunakan uji Levene sig $\geq 0,05$ maka $\mathrm{H}_{0}$ diterima, sedangkan sig $<0,05 \mathrm{H}_{0}$ ditolak. Dengan demikian diketahui bahwa diterima $\mathrm{H}_{1}$ yaitu terdapat perbandingan model pembelajaran Discovery Learning dan Numbered Heads Together melalui media Word Square terhadap hasil belajar kognitif peserta didik pada sub materi stoikiometri di SMA Negeri 1 Dewantara.

Berdasarkan hasil pretes dan postes yang telah diuraikan, maka data menunjukkan bahwa terdapat perbandingan model pembelajaran Discovery Learning dan Numbered Heads Together melalui media Word Square terhadap hasil belajar kognitif peserta didik pada sub materi stoikiometri di SMA Negeri 1 Dewantara. Pretes bertujuan untuk melihat kemampuan awal peserta didik. Menurut Purwanto (1998: 38) pretes adalah tes yang diberikan sebelum pelajaran dimulai dengan tujuan untuk mengetahui sejauh mana penguasaan peserta didik terhadap bahan pengajaran yang akan diajarkan. Postes bertujuan untuk melihat hasil belajar peserta didik setelah diberi perlakuan dan diajarkan materi yang dipelajari. Hanik dkk (2016: 4) mengungkapkan bahwa postes juga merupakan salah satu cara atau sarana untuk mengetahui tingkat penguasaan materi atau sebagai alat untuk mengukur prestasi belajar peserta didik. Hasil penelitian ini diperoleh hasil pretes lebih kecil dari pada hasil postes (dapat dilihat pada tabel 2).

Hasil belajar kognitif peserta didik setelah diajarkan dengan menggunakan model pembelajaran Discovery Learning dan Numbered Heads Together melalui media Word Square mengalami peningkatan. Hal ini disebabkan pada kelas eksperimen yang diajarkan menggunakan model pembelajaran Discovery Learning, peserta didik belajar secara langsung dan tidak terpaku pada materi yang disampaikan oleh guru. Sesuai dengan hasil penelitian yang dilakukan oleh Cintia dkk (2018) bahwa, model pembelajaran Discovery Learning merupakan model pembelajaran yang 
mengarahkan peserta didik menemukan konsep melalui berbagai informasi atau data yang diperoleh melalui pengamatan dan percobaan. Peserta didik dihadapkan pada suatu permasalahan terlebih dahulu, dalam hal ini peneliti memberikan soalsoal berbentuk Word Square pada LKPD yang dikerjakan secara berkelompok. Peserta didik mencari solusi atas penyelesaian soal-soal tersebut secara bebas sesuai kemampuan mereka tanpa diberi materi terlebih dahulu. Menurut Setiaji dkk (2018) model pembelajaran Discovery Learning dapat melatih peserta didik belajar secara bekerja sama, melatih kemampuan bernalar peserta didik, serta melibatkan peserta didik secara aktif dalam proses pembelajaran untuk menemukan dan memecahkan masalah dengan atau tanpa bantuan orang lain.

Pemahaman konsep menjadi lebih dalam ketika peserta didik memaknai proses pembelajaran dengan baik sehingga menimbulkan rasa percaya diri peserta didik. Peserta didik diberi materi ketika mereka telah menyelesaikan dan membahas LKPD secara bersama. Peneliti memberi penguatan dan menyampaikan materi pada tahap ini. Penyerapan materi pelajaran pada kelas eksperimen dapat diterima dengan maksimal karena peserta didik dilibatkan secara aktif. Peserta didik tidak hanya berperan aktif sebagai penerima pengetahuan, tetapi peserta didik juga dituntut menemukan materi pelajaran secara mandiri. Hal ini berbeda dengan kelas kontrol, dimana materi yang diajarkan disampaikan terlebih dahulu sebelum mengerjakan LKPD secara berkelompok.

Peran guru dalam proses pembelajaran ini adalah sebagai fasilitator. Guru membimbing dan membantu peserta didik ketika menghadapi kesulitan, sedangkan peserta didik yang kurang bersemangat diberi motivasi, arahan dan petunjuk agar mereka menemukan solusi terhadap permasalahan yang dihadapinya. Hal ini dibuktikan dengan banyaknya peserta didik yang mengacungkan tangan ketika menjawab soal maupun bertanya ketika mereka menemukan kesulitan. Hasil penelitian ini sejalan dengan hasil penelitian yang diterapkan oleh Mubarok dan Sulistyo (2014) yang menyatakan bahwa, diperoleh hasil belajar peserta didik yang menggunakan model pembelajaran Discovery Learning lebih tinggi dari pada yang menggunakan pembelajaran langsung. Sehingga dapat dikatakan bahwa model pembelajaran Discovery Learning berpengaruh positif terhadap hasil belajar peserta didik. Hasil penelitian yang dilakukan oleh Yuliana (2018) bahwa, penerapan model pembelajaran Discovery Learning sangat membantu dalam upaya guru meningkatkan hasil belajar peserta didik dan tidak hanya itu, model ini juga membantu meningkatkan kemampuan bekerja mandiri dalam pemecahan masalah. Putri dkk (2017) menyatakan bahwa, hasil pengamatan peneliti selama melaksanakan penelitian tampak bahwa semangat dan pemahaman siswa yang diajarkan dengan model pembelajaran Discovery Learning lebih baik jika dibandingkan dengan menggunakan model pembelajaran konvensional yang dilihat dari hasil belajar peserta didik.

Hal ini juga sesuai dengan hasil analisis uji hipotesis yang diperoleh dengan nilai sig (2-tailed) sebesar 0,022. Sesuai dengan kaidah keputusan menggunakan uji Levene sig $\geq 0,05$ maka $\mathrm{H}_{0}$ diterima, sedangkan sig $<0,05 \mathrm{H}_{0}$ ditolak. Hasil penelitian ini sejalan dengan hasil penelitian yang dilakukan oleh Dali dkk (2018) yang menunjukkan bahwa nilai probabilitas sebesar $0,000<$ 0,05 maka $\mathrm{H}_{0}$ ditolak, artinya terdapat perbedaan yang signifikan antara peningkatan penguasaan konsep peserta didik yang diajarkan dengan PBL 
berbasis pendekatan saintifik dengan model pembelajaran langsung pada pokok bahasan kelarutan dan hasil kali kelarutan. Maka terbukti bahwa terdapat perbedaan yang signifikan terhadap hasil belajar kognitif peserta didik yang diajarkan menggunakan model pembelajaran Discovery Learning melalui media Word Square.

\section{KESIMPULAN}

Berdasarkan penelitian yang telah dilakukan maka dapat disimpulkan bahwa terdapat perbandingan model pembelajaran Discovery Learning dan Numbered Heads Together melalui media Word Square terhadap hasil belajar kognitif peserta didik pada sub materi stoikiometri di SMA Negeri 1 Dewantara, dibuktikan dengan nilai ratarata pretes kelas eksperimen yang diajarkan menggunakan model pembelajaran Discovery Learning sebesar 4,56 meningkat pada postes sebesar 16,29 dengan standar deviasi 2,329, sedangkan nilai rata-rata pretes kelas kontrol yang diajarkan menggunakan model pembelajaran Numbered Heads Together sebesar 4,41 meningkat pada postes sebesar 14,88 dengan standar deviasi 2,685 .

\section{DAFTAR PUSTAKA}

Cintia, N. I., Kristin, F. dan Anugraheni, I. 2018. "Penerapan Model Pembelajaran Discovery Learning untuk Meningkatkan Kemampuan Berpikir Kreatif dan Hasil Belajar Siswa". Jurnal. Volume 32, No. 1. April 2018: 69-77.

Dali, A., Rafiuddin, R. dan Anton, L. O. R. 2018. "Penerapan Model Problem Based Learning (PBL) Berbasis Pendekatan Saintifik untuk Meningkatkan Penguasaan Konsep pada Materi Pokok Kelarutan dan Hasil Kali Kelarutan". Jurnal. Volume 8, No. 2. 2018: 1-10.

Hanik, N. R., Harsono, S. dan Wiharti, T. 2016. "Peningkatan Aktivitas dan Prestasi Belajar Mahasiswa melalui Pemberian Post Test pada Mata Kuliah Telaah Kurikulum dan Perangkat Pembelajaran Biologi Sekolah Menengah Atas dengan Pendekatan Terpadu". Jurnal. Volume 4, No. 1. Maret 2016: 1-7.

Kurniawati, E., Kurniati, T. dan Kurniawan, R. A. 2017. "Deskripsi Kemampuan Matematika dan Korelasinya dengan Hasil Belajar pada Mata Pelajaran Kimia Kelas X MIPA SMA Negeri 4 Pontianak." Jurnal Ilmiah. Volume 5, No. 2. Februari 2017: 169-180.

Monasari, J. S. dan Pintor S. 2018. "Pengaruh Model Pembelajaran Discovery Learning terhadap Hasil Belajar Siswa pada Materi Pokok Momentum, Impuls dan Tumbukan Kelas X Semester II di SMA N 1 Pancurbatu TP. 2016/2017”. Jurnal Inovasi Pembelajaran Fisika (Inpafi). Volume 6, No. 4. Nopember 2018: 28-39.

Mubarok, C. dan Sulistyo E. 2018. "Penerapan Model Pembelajaran Discovery Learning terhadap Hasil Belajar Siswa Kelas X TAV pada Standar Kompetensi Melakukan Instalasi Sound System di SMK Negeri 2 Surabaya". Jurnal Pendidikan Teknik Elektro. Volume 3, No. 1. 2014: 215-221. .

Purwanto, M. N. 2010. Prinsip-prinsip dan Teknik Evaluasi Pengajaran. Bandung: PT Remaja Rosdakarya. 
Putrayasa, I. M., Syahruddin H., dan Margunayasa I. G. 2014. "Pengaruh Model Pembelajaran Discovery Learning dan Minat Belajar terhadap Hasil Belajar IPA Siswa". Jurnal Mimbar PGSD. Volume, 2 No. 1. Singaraja: Universitas Pendidikan Ganesha.

Putri, I. S., Juliani, R. dan Lestari, I. N. 2017. "Pengaruh Model Pembelajaran Discovery Learning terhadap Hasil Belajar dan Aktivitas Siswa". Jurnal. Volume 6, No. 2. 2017: 91-94.

Setiaji, D. W. S., Kristin, F. dan Anugraheni, I. 2018. "Penerapan Model Pembelajaran Discovery Learning untuk Meningkatkan Kerja Sama dan Hasil Belajar IPA pada Siswa Sekolah Dasar". Jurnal. Volume 6, No. 2. 2018: 20-25.

Sugiyono. 2016. Metode Penelitian Pendidikan. Bandung: Alfabeta.

Widodo, H. 2015. "Potret Pendidikan di Indonesia dan Kesiapan dalam Menghadapi Masyarakat Ekonomi Asia (MEA)". Jurnal. Volume 13, No. 2. Desember 2015: 294-307.

Yuliana, N. 2018. "Penggunaan Model Pembelajaran Discovery Learning dalam Peningkatan Hasil Belajar Siswa Di Sekolah Dasar". Jurnal Ilmiah Pendidikan dan Pembelajaran. Volume 2, No.1. April 2018: 21-28. 